\title{
SINTESIS DAN KAREKTERISASI SENYAWA KIRAL HASIL REAKSI ANTARA METILEUGENOL KASAR DENGAN ASAM ASETAT
}

\section{[Synthesis and Characterization of Chiral Compounds From The Rough Methyleugenol With Acetic Acid]}

\author{
Muh. Hajir S. Lasapo ${ }^{1^{*}}$, Erwin Abdul Rahim ${ }^{1}$, Ruslan $^{1}$, Indriani $^{1}$ \\ 1) Jurusan Kimia Fakultas MIPA Universitas Tadulako \\ Jl. Soekarno Hatta Km.9, Kampus Bumi Tadulako Tondo Palu, Telp. 0451 - 422611
}

Diterima 2 Mei 2016, Disetujui 6 Agustus 2016

\begin{abstract}
The research about synthesis and characterization of chiral compounds from the rough methyleugenol with acetic acid as the catalyst has been done. The goal is to determine the content of 1-(3,4dimetoksifenil)-2-propanil acetate compound which is produced in the reaction process of metileugenol with acetic acid and to characterizased the chemical compound of the product. The results showed that the content of 1-(3,4-dimetoksifenil)-2-propanil acetate compound that has been obtained was $45.87 \%$ with a molecular weight of 238 .
\end{abstract}

Keywords : Methyleugenol, Chiral, FT-IR, GC-MS

\begin{abstract}
ABSTRAK
Telah dilakukan penelitian tentang sintesis dan karakterisasi senyawa kiral hasil reaksi antara metileugenol kasar dengan asam asetat. Tujuannya adalah untuk mengetahui kadar senyawa 1-(3,4dimetoksifenil)-2-propanil asetat pada proses reaksi metileugenol kasar dengan asam asetat dan karakterisasinya. Metode yang digunakan yaitu dengan menggunakan reaksi adisi dalam proses sintesis. Hasil analisis dengan menggunakan GC-MS diperoleh kadar senyawa 1-(3,4-dimetoksifenil)2-propanil asetat dari sampel metileugenol kasar yang direaksikan dengan asam asetat sebesar $45,87 \%$ dengan berat molekul sebesar 238 .
\end{abstract}

Kata Kunci : Metileugenol, Kiral, FT-IR, GC-MS 


\section{LATAR BELAKANG}

Senyawa kiral adalah ketika empat ligan yang berbeda terikat kepada karbon tetravalent, menghasilkan molekul asimetris yang mana atom karbon sebagai pusat asimetrisnya. Senyawa kiral mempunyai jumlah yang cukup besar dari ribuan bahan kimia yang telah digunakan. Sebagian masyarakat mungkin kurang memperhatikan sifat optis suatu senyawa organik, padahal reaksi kimia dalam sistem biologis makhluk hidup sangat stereospesifik. Artinya suatu stereoisomer akan menjalani reaksi yang berbeda dengan stereoisomer pasangannya dalam sistem biologis makhluk hidup. Bahkan terkadang suatu stereoisomer akan menghasilkan produk yang berbeda dengan stereoisomer pasangannya dalam sistem biologis makhluk hidup (Fendy, 2007).

Penelitian mengenai senyawa eugenol banyak dilakukan karena sering dimanfaatkan dalam berbagai industri sehingga diharapkan dalam penelitian ini agar didapatkan manfaat metil eugenol yang lebih optimal sehingga dapat diubah menjadi bahan dasar untuk pembuatan senyawa-senyawa yang lebih berdaya guna salah satunya senyawa 1-(3,4 Dimetoksi Fenil)-2-Propanon yang merupakan bahan dasar dalam pembuatan a-metil DOPA. Didalam dunia kedokteran senyawa a-metil DOPA digunakan sebagai obat anti Parkinson (Widowati, 2011).
Senyawa yang analog dengan 1-(3,4dimetoksifenil)-2-propanon yaitu 1-(3,4metilendioksifenil)-2-propanon telah dapat buat dari safrol melalui adisi dengan asam format diikuti dengan hidrolisis dan oksidasi dengan piridinium klorokromat, PCC. Metode adisi asam format ini sangat sederhana untuk dikerjakan dan telah dicoba untuk metileugenol dalam pembuatan senyawa dasar 1-(3,4dimetoksifenil)-2-propanon yang dari bahan dasar ini dapat dibuat senyawa analog L-alfa- metil DOPA (Sohilait dkk, 2005).

Penelitian lain tentang sintesis metileugenol format yang disintesis dengan cara formilasi asam format Andriyani (2008) dan sintesis senyawa 3(3,4-dimetoksifenil)-1-propanol yang disintesis melalui reaksi hidroborasi metileugenol menggunakan $\mathrm{H}_{3} \mathrm{~B}$ :dietileter pada suhu $0^{\circ} \mathrm{C}$ dan kondisi inert untuk menghasilkan trialkilborana Fatoni (2005), serta sintesis senyawa 3-(3,4-dimetoksi fenil)-propanol yang disintesis dengan reaksi oksidasi menggunakan oksidator piridinium klorokromat (Ngadiwiyana, dkk, 2007).

Dari sekian banyak turunannya ini membuktikan bahwa metileugenol dapat dimanfaatkan untuk meningkatkan nilai ekonomis dari cengkeh, terutama turunannya yang bersifat senyawa yang kiral dari metileugenol salah satunya yaitu senyawa (S)-(3,4-dimetoksifenil)-2propanol. 
Eugenol mempunyai gugus alil dan hidroksil. Gugus hidroksi dapat digantikan dengan gugus metil sehingga menghasilkan metil eugenol. Gugus alil yang dapat diadisi dengan asam asetat menghasilkan senyawa ester kiral (Rahim, 2015).

Penelitian terbaru yang dilakukan oleh Rahim (2015), dalam laporan penelitian mandiri tentang sintesis metil eugenol menggunakan reaksi adisi dengan asam asetat yang telah dicampurkan beberapa tetes asam sulfat diperoleh senyawa 1(3,4-dimetoksifenil)-2-propanil asetat. Selanjutnya dilakukan proses hidrolisis menggunakan $\mathrm{KOH}$. Menurut Putri, dkk (2014), pemilihan $\mathrm{KOH}$ sebagai reaktan dikarenakan sifatnya yang lebih cepat larut dalam air dan pengikatan asam lebih cepat dibandingkan dengan senyawa basa yang lain, hal ini dapat mempersingkat proses pemurnian. Apalagi senyawa kiral tersebut diperoleh dari reaksi senyawa yang bukan kiral. Menurut White (1991), pada umumnya dalam sintesis memerlukan bahan dasar kiral atau dengan mengunakan katalis kiral untuk menginduksi substrat prokiral. Sedangkan menurut Caswell (1993), senyawa yang memutar bidang polarisasi cahaya (optis aktif) dapat dibuat dari bahan dasar dan pereaksi yang bukan kiral tanpa ada pengaruh dari senyawa optis aktif, proses ini dinamakan "Absolute Asymmetric Synthesis'.

Menurut Ariens (1987), untuk memproduksi senyawa kiral dalam bentuk enantiomer murni memerlukan biaya yang lebih mahal dan $98 \%$ obat yang diperoleh dari alam atau semisintesis berupa senyawa kiral dan dijual dalam bentuk enantiomer murni.

Akan tetapi dengan mengsintesis senyawa metil eugenol dengan asam asetat yang bukan senyawa kiral diperoleh senyawa kiral yang menghasilkan produk enantiomer yang optis aktif dengan kemurnian enantiomer 92,22\% (e.e $=92,22 \%$ ) sedangkan pada proses hidrolisis menghasilkan kemurnian enantiomer 100\% (Rahim, 2015).

Dalam penelitian ini belum dilakukan proses sintesis dengan menggunakan sampel metileugenol kasar dan karakterisasi untuk menghasilkan senyawa kiral yang lebih mudah untuk diperoleh dan tentunya sangat bermanfaat bagi manusia terutama dalam pembuatan obat-obatan dengan bahan dasar senyawa kiral maupun pembuatan katalis kiral sehingga dapat menjadi dasar bagi para peneliti yang ingin mengembangkan senyawa tersebut menjadi produk obatobatan yang bermanfaat bagi kehidupan masyarakat dan juga meningkatkan nilai ekonomis dari minyak cengkeh tersebut.

\section{METODE PENELITIAN}

\section{Bahan dan Alat}

Bahan yang digunakan dalam penelitian ini meliputi, metileugenol kasar, silika gel $60 \mathrm{G}$, asam asetat glasial, etil asetat, $\mathrm{NaHCO}_{3} 10 \%$, Kalium Hidroksida $0,002 \mathrm{M}$, asam sulfat pekat, $\mathrm{n}$-heksana, 
etanol, dietil eter, natrium sulfat anhidrat, plat KLT, tisu dan aquades.

Alat yang digunakan dalam penelitian ini meliputi satu set alat kromatografi kolom, labu alas bulat, Corong pisah, satu set alat refluks, satu set alat destilasi, lampu Uv merk Camag (254 nm dan 366 $\mathrm{nm})$, lemari asam, satu set alat evaporator, alat GC, GC-MS dan FT-IR, Alat-alat gelas laboratorium, $\mathrm{pH}$ meter, corong pisah, magnet stirer, statif dan klem, timbangan analitik digital, penangas minyak dan batang pengaduk serta thermometer.

\section{Prosedur Penelitian}

\section{Karakterisasi Metileugenol Kasar}

Proses identifikasi sifat fisik metil eugenol yang terapat dalam sampel petrogenol akan digunakan dalam penelitian dan untuk mengetahui tingkat kemurnian metileugenol dilakukan proses analisis dengan menggunakan FT-IR dan GC.

\section{Reaksi Adisi Metileugenol kasar dengan Asam Asetat (Rahim, 2015)}

Ke dalam labu alas bulat kapasitas $250 \mathrm{~mL}$ dimasukan $10 \mathrm{~mL}$ metil eugenol, ditambahkan $100 \mathrm{~mL}$ asam asetat yang telah diberikan $\mathrm{H}_{2} \mathrm{SO}_{4}$ beberapa tetes. Kemudian dilakukan refluks selama 5 jam pada suhu $180^{\circ} \mathrm{C}$. Setelah refluks selesai campuran didinginkan kemudian didistilasi dengan suhu 115-118 ${ }^{\circ} \mathrm{C}$ untuk memisahkan asam asetat glasial yang tersisa. Residu ditambahkan dengan 100 $\mathrm{mL}$ dietil eter sehingga terbentuk dua lapisan. Kemudian dinetralkan dengan $\mathrm{NaHCO}_{3} 10 \%$, lapisan bawah dibuang. Lapisan atas dicuci dengan aquades dan kemudian dikeringkan dengan $\mathrm{Na}_{2} \mathrm{SO}_{4}$ anhidrous, selanjutnya didekantir. Pelarut dietil eter dipisahkan dengan menggunakan evaporator.

\section{Pemisahan Hasil Sintesis dengan Kromatografi Kolom.}

\section{a. Penyiapan kolom}

Bubur dari $20 \mathrm{~g}$ silika gel 60 G (230400 mesh ASTM, E Merck) dalam $500 \mathrm{~mL}$ n-heksana : etil asetat dimasukkan ke dalam tabung kolom kaca panjang $50 \mathrm{~cm}$ diameter $2 \mathrm{~cm}$. Setelah silika gelnya mampat, kelebihan pelarut dikeluarkan hingga batas atas (Muchalal dan Rahayu, 2002)

\section{b. Pemisahan sampel}

Hasil sintesis digunakan dalam proses pemisahan. Eluen yang digunakan adalah campuran n-heksana-etil asetat (Muchalal dan Rahayu, 2002). Eluat ditampung dalam tabung reaksi. Penampungan eluat dimulai setelah eluen yang diperkirakan terjebak dalam fasa diam telah keluar. Berdasarkan penampakan fisik hasil yang diperoleh dikelompokkan menjadi beberapa fraksi. Fraksi-fraksi dianalisis dengan KLT untuk mengetahui penampakan noda, penampakan noda yang sama di campur menjadi 1 bagian dan di pekatkan menggunakan rotary evavorator untuk menghilangkan pelarutnya dan dianalisis dengan FT-IR dan GC-MS. Perbandingan pelarut yang digunakan dalam kromatografi kolom 
ditentukan dari hasil uji kromatografi lapis tipis (TLC) menggunakan pelat silika gel 60 F254 (E Merck).

\section{HASIL DAN PEMBAHASAN}

\section{Sifat Fisik Metileugenol Kasar}

Penelitian ini menggunakan bahan dasar metil eugenol (Petrogenol). Tahap awal karakterisasi metil eugenol dilakukan berdasarkan identifikasi fisik. Identifikasi fisik dilakukan bertujuan untuk mengetahui wujud, warna, dan bau metil eugenol. Hasil identifikasi sifat fisik dari senyawa metil eugenol dapat dilihat pada Tabel 1.

Tabel 1. Sifat Fisik Senyawa Metileugenol Kasar

\begin{tabular}{ccc}
\hline No & Sifat fisik & Keterangan \\
\hline 1 & Wujud & Cair \\
\hline 2 & Warna & Kuning Muda \\
\hline 3 & Bau & Minyak cengkeh \\
\hline
\end{tabular}

Hasil tersebut tidak sesuai dengan literatur, Menurut Widowati (2011) yang menjelaskan bahwa wujud metileugenol berbentuk cair dan berbau minyak cengkeh. Namun, ada perbedaan warna metil eugenol dari hasil yang diperoleh berwarna kuning muda, sedangkan hasil literatur menyebutkan metileugenol berwarna jernih. Perbedaan sifat fisik warna metileugenol ini kemungkinan disebabkan oleh tingkat kemurnian yang berbeda. Selanjutnya untuk mengetahui tingkat kemurnian metileugenol dilakukan proses analisis lebih lanjut.

\section{Hasil analisis metileugenol kasar dengan spektrofotometer infra merah.}

Analisis dengan spektrofotometer pada metileugenol kasar menunjukkan spektrum seperti terlihat pada Gambar 1.

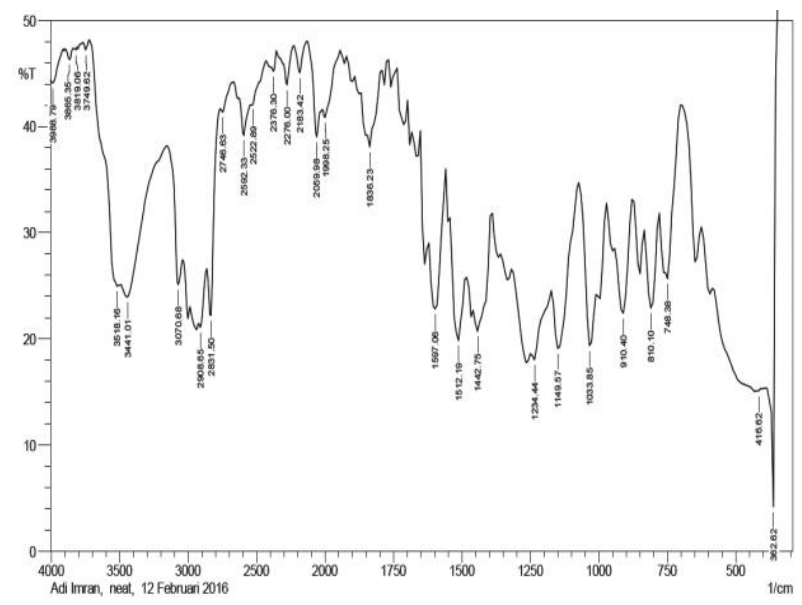

Gambar 1. Hasil analisis Spektrofotometri Infra merah metil eugenol (petrogenol)

Berdasarkan Gambar diatas diketahui bahwa pada spektrum IR yang diperoleh memperlihatkan adanya :

1. Gugus propenil yang ditunjukkan oleh serapan pada $2908,65 \mathrm{~cm}^{-1}$ dari gugus $\mathrm{CH}$ (rentangan) dan $1442,75 \mathrm{~cm}^{-1}$ dari gugus $\mathrm{CH} 2$ (bengkokan) Gugus metoksi yang ditunjukkan oleh serapan pada 1234,44 $\mathrm{cm}^{-1}$ (rentangan asimetris) dan $1149,57 \mathrm{~cm}^{-1}$ (rentangan simetris) dari C-O.

2. Cincin aromatis yang ditunjukkan oleh serapan pada $1589,34 \mathrm{~cm}^{-1}$ dari gugus $\mathrm{C}=\mathrm{C}$ (rentangan), $3070,68 \mathrm{~cm}^{-1}$ dari gugus $=\mathrm{CH}$ (rentangan).

3. Gugus hidroksil yang ditunjukan pada serapan $3441,01 \mathrm{~cm}^{-1}$

Dari hasil analisis dengan FT-IR diatas dapat dinyatakan senyawa yang dianalisis mengandung gugus propenil, 
metoksi, dan cincin aromatis serta hidroksil. Dengan adanya gugus hidroksil yang terdapat pada hasil spektrum IR tersebut ini menandakan bahwa sampel yang digunakan masi mengandung senyawa eugenol dan ketiga gugus selain gugus hidroksil tersebut dimiliki senyawa metil eugenol, sehingga dimungkinkan bahwa senyawa yang dianalisis merupakan campuran eugenol dan metil eugenol.

\section{Hasil analisis metileugenol kasar dengan Gas Cromatografi (GC).}

Hasil analisis dengan GC untuk sampel metileugenol kasar terlihat pada Gambar 2.

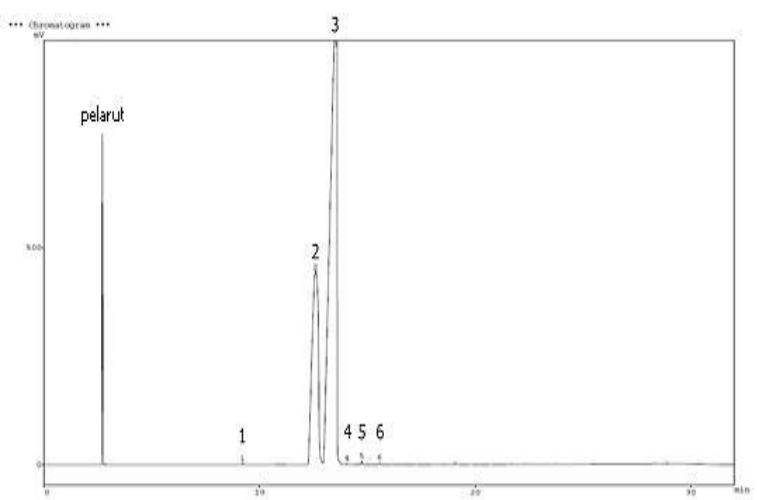

Gambar 2. Hasil analisis Gas Cromatografi (GC) metileugenol kasar

Dari hasil analisis dengan menggunakan gas cromatografi (GC) terlihat dengan jelas pada kromatogram pada tingkat persentasi pada puncak 2 merupakan senyawa eugenol dengan persentase $27,71 \%$. Sedangkan pada puncak 3 merupakan senyawa metil eugenol dengan persentase tertinggi yaitu $71,89 \%$. Sampel yang digunakan tidak murni metileugenol yang disebabkan adanya kandungan senyawa eugenol yang teridentifikasi pada saat analisis. Hal ini dibuktikan dengan adanya gugus hidroksil yang teridentifikasi pada hasil analisis FT-IR yang menandakan adanya senyawa eugenol.

Dari hasil analisis sampel metil eugenol (petrogenol) dengan menggunakan FT-IR dan GC dapat disimpulkan bahwa sampel yang digunakan merupakan campuran senyawa eugenol dan metil eugenol. Jadi, sampel yang digunakan pada penelitian ini bukan merupakan sampel murni metileugenol.

\section{Reaksi Adisi Metileugenol Kasar dengan Asam Asetat}

Pada reaksi adisi yang dilakukan pada suhu ruang, senyawa asam asetat mengalami disosiasi yang selanjutnya terjadi reaksi adisi terhadap metil eugenol. Senyawa metil eugenol merupakan sebuah alkena tak-simetris (yakni gugusgugus yang terikat pada kedua karbon $s p^{2}$ tidak sama), sehingga ada dua kemungkinan produk isomerik yang akan dihasilkan, namun satu isomerik lebih melimpah (Fesssenden \& Fesssenden, 1982). Pada proses reaksi adisi metil eugenol dengan asam asetat kemungkinan besar diperoleh senyawa 1(3,4-dimetoksi fenil)-2-propanil asetat (Gambar 3).

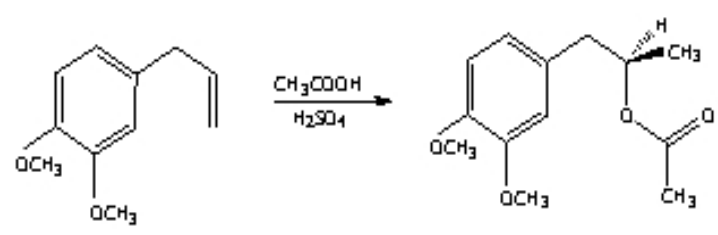

Gambar 3. Reaksi metileugenol dengan asam asetat (Rahim, 2015). 
Kebenaran struktur senyawa 1-(3,4dimetoksi fenil)-2-propanil asetat pada gambar diatas perlu dilakukan analisis lanjutan dengan ${ }^{1} \mathrm{NMR}$ untuk mengtahui kebenaran dari struktur tersebut, sehingga diperoleh data yang otentik mengenai kebenaran senyawa yang diperoleh. Pada penelitian sebelumnya yang dilakukan oleh Rahim (2015) diperoleh senyawa 1(3,4-dimetoksi fenil)-2-propanil asetat sebesar 7,68\% yang dianalisis menggunakan HPLC dan ${ }^{1} \mathrm{NMR}$. Sedangkan pada penelitian ini diperoleh hasil yang sangat tinggi yang kemungkinan besar adalah senyawa 1(3,4-dimetoksi fenil)-2-propenil asetat dengan nilai persentase tertinggi yaitu $45,87 \%$. Hasil yang diperoleh ini berpeluang besar untuk meningkatkan nilai ekonomis dari minyak cengkeh.

Seperti yang terlihat pada Gambar 4.

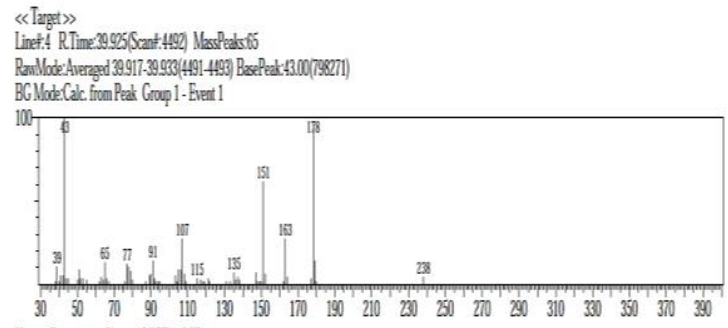

Gambar 4. Analisis MS Puncak 4

Struktur senyawa 1-(3,4-dimetoksi fenil)-2-propanil asetat merupakan salah satu senyawa kiral. Terlihat satu atom karbon pada propanil mengikat 4 gugus yang berlainan. Menurut Fesssenden \& Fesssenden (1982) ciri struktur yang sangat lazim yang menyebabkan terjadinya kiralitas dalam molekul ialah bahwa molekul itu mengandung sebuah atom karbon dengan 4 gugus yang berlainan (atom karbon kiral).

\section{Hasil Pemisahan dengan Kromatografi Kolom.}

Dari hasil pemisahan dengan menggunakan kromatografi kolom diperoleh 18 fraksi, yang kemudian dikelompokkan berdasarkan penampakan fisik yang berupa warna. Dari 18 fraksi yang diperoleh memiliki warna yang sama yaitu orange muda. Dari analisis KLT terlihat pada Gambar 5.

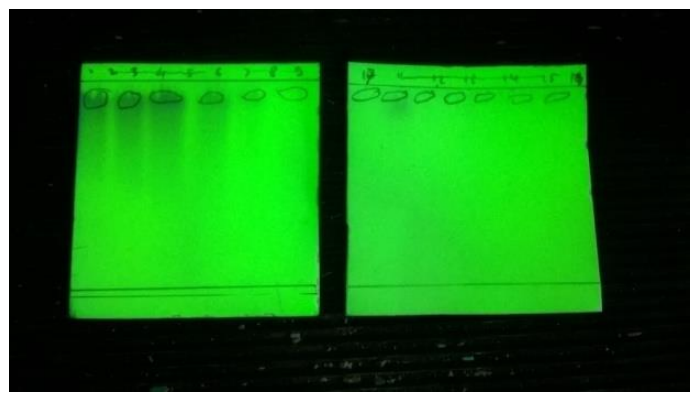

Gambar 5. Analisis KLT Hasil Pemisahan kromatografi kolom.

Sehingga kemungkinan senyawa dalam masing-masing tabung sama. Dari 18 tabung reaksi tersebut disatukan kedalam labu rotary untuk dilakukan proses pemekatan dengan cara menghilangkan pelarut yang bercampur pada sampel hasil pemisahan kromatografi kolom. Untuk pelarut yang digunakan yaitu $n$-heksan : etil asetat dengan perbandingan 1 : 4 . Hasil perbandingan ini diperoleh dengan penentuan dari hasil uji kromatografi lapis tipis (KLT) menggunakan plat silika gel 60 F254 (E Merck).

\section{Hasil Pemisahan dengan FT-IR}

Hasil analisis dari FT-IR pada sampel pemisahan dengan menggunakan 
kromatografi kolom dapat dilihat pada Gambar 6.

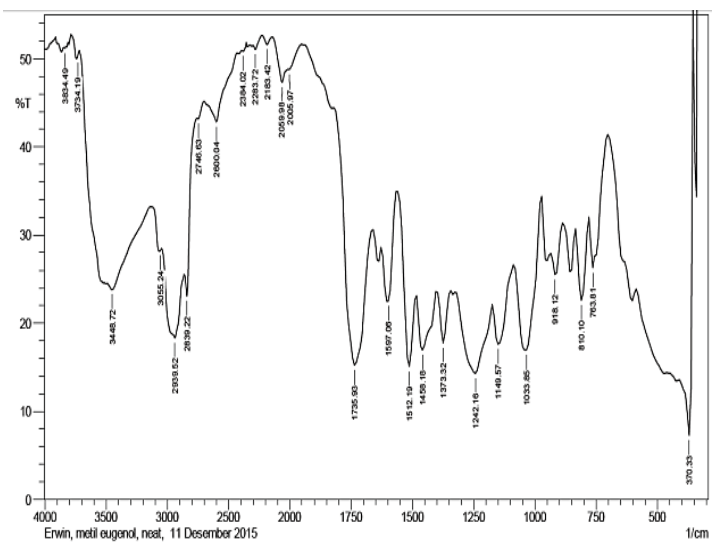

Gambar 6. Hasil analisi spektrofotometri infa merah sampel hasil pemisahan

Dari Gambar diatas diketahui bahwa pada spektrum IR yang diperoleh memperlihatkan adanya :

1. Gugus karbonil berada pada serapan bilangan gelombang $1735,93 \mathrm{~cm}^{-1}$.

2. Cincin aromatis berada pada serapan bilangan gelombang $1597,06 \mathrm{~cm}^{-1}$.

3. Gugus propenil yang ditunjukkan oleh serapan pada $3055,24 \mathrm{~cm}^{-1}$ dari gugus $\mathrm{CH}$ (rentangan), dan serapan pada $1458,18 \mathrm{~cm}^{-1}$ dari gugus $\mathrm{CH} 2$ (bengkokan)

4. Gugus metoksi pada serapan 1242,16 $\mathrm{cm}^{-1}$ (rentangan asimetris) dan $1149,57 \mathrm{~cm}^{-1} \quad$ (rentangan simetris) dari C-O.

5. Gugus hidroksil pada serapan bilangan gelombang $3448,72 \mathrm{~cm}^{-1}$.

Untuk mengetahui lebih jelasnya senyawa yang terbentuk dilakukan proses analisis dengan menggunakan GC-MS.

\section{Hasil Pemisahan dengan GC-MS}

Hasil analisis dari GC-MS pada sampel isolasi dengan menggunakan kromatografi kolom dapat dilihat pada Gambar 7.

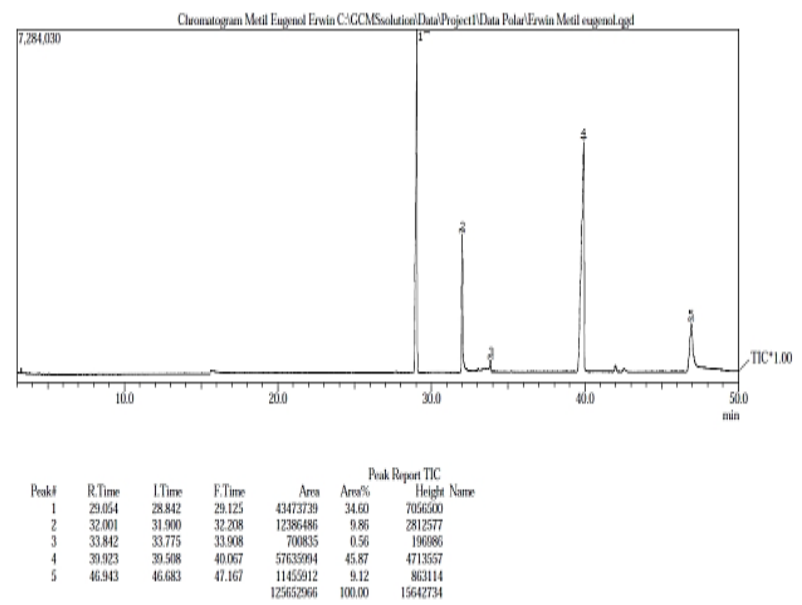

Gambar 7. Kromatogram GC sampel hasil pemisahan

Dari hasil kromatogram GC pada gambar diatas dapat terliat ada 5 puncak yang teridentifikasi. Pada puncak 1 pada kromatogram GC diduga merupakan senyawa kristal kiral dari metileugenol dengan berat molekul 178. Seperti terlihat pada Gambar 8.

liber

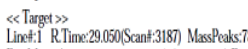

Linefil RT. BC Modec Calc from Peak Group 1- Fuent I

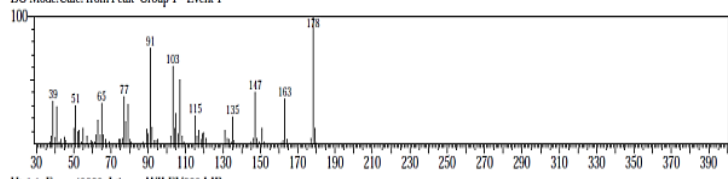

Gambar 8. Mass peaks MS puncak 1

Dari analisis FT-IR pada Gambar diatas diperoleh gugus propanil yang ditunjukkan oleh serapan pada 3055,24 $\mathrm{cm}^{-1}$ dari gugus $\mathrm{CH}$ (rentangan), dan serapan pada $1458,18 \mathrm{~cm}^{-1}$ dari gugus $\mathrm{CH} 2$ (bengkokan), cincin aromatis pada bilangan gelombang 1597,06 $\mathrm{cm}^{-1}$ dan gugus metoksi pada bilangan gelombang $1242,16 \mathrm{~cm}^{-1}$. 
Pada puncak 2 senyawa yang teridentifikasi kemungkinan senyawa eugenol dengan berat molekul 164. Dari mass peaks MS dapat dilihat pada Gambar 9.

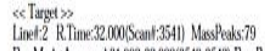

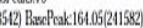

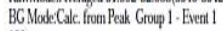

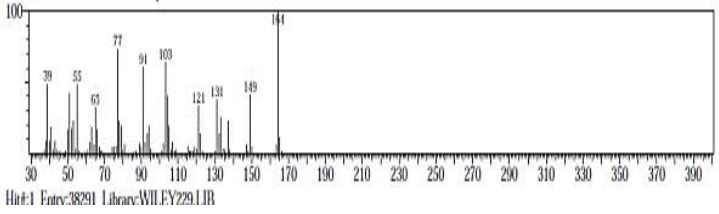

Gambar 9. Mass peaks MS puncak 2

Dari analisis FT-IR diperoleh gugus hidroksil $(\mathrm{OH})$ pada bilangan gelombang $3448,72 \mathrm{~cm}^{-1}$, cincin aromatis pada bilangan gelombang $1597,06 \mathrm{~cm}^{-1}$ dan gugus propanil yang ditunjukkan oleh serapan pada $3055,24 \mathrm{~cm}^{-1}$. Untuk tingkat kadar yang diperoleh yaitu 9,86\%. Bila dibandingkan dengan hasil analisis pada sampel, kandungan eugenol pada sampel yaitu $27,71 \%$. Berkuranganya produksi eugenol pada tahap pemisahan dengan kromatografi kolom menandakan senyawa eugenol bereaksi dengan asam asetat.

Pada puncak 3 dengan tingkat persentase $0,56 \%$ dimungkinkan senyawa asetil eugenol. Berat molekul pada mass peaks MS yaitu 206, seperti yang terlihat pada Gambar 10.

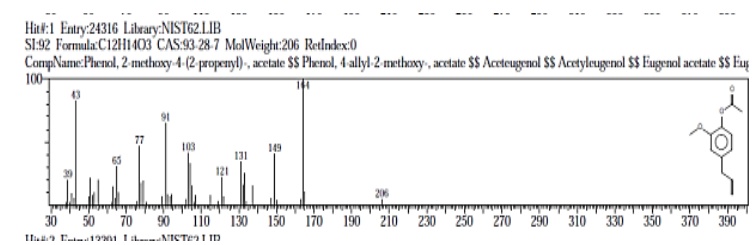

Gambar 10. Mass peaks puncak 3

Dari analisis dengan FT-IR terlihat gugus fungsi karbonil (ester) pada bilangan gelombang $1735,93 \mathrm{~cm}^{-1}$, gugus fungsi metoksi berada pada bilangan gelombang $1242,16 \mathrm{~cm}^{-1}$, cincin aromatis pada bilangan gelombang 1597,06 $\mathrm{cm}^{-1}$ dan gugus propenil pada bilangan gelombang 2908,65 $\mathrm{cm}^{-1}$. Data hasil analisis dengan FT-IR dan GC-MS kemungkinan senyawa yang terdapat pada puncak 3 adalah asetil eugenol.

Pada puncak nomor 5 kemungkinan senyawa 1-(3-metoksi-4-hidroksi-fenil)-2propanil asetat yang terbentuk dari reaksi antara senyawa eugenol dengan asam asetat. Persentase yang diperoleh dari kromatogram puncak nomor 5 sebesar $9,12 \%$. Sedangkan pada mass peaks MS terlihat berat molekul yang diperoleh yaitu 224, seperti pada Gambar 11.

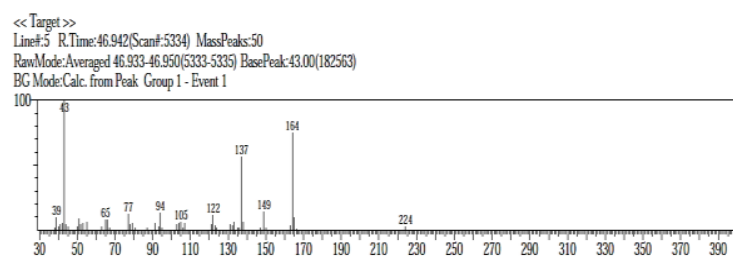

Gambar 11. Mass peaks MS puncak 5

Dari data analisis FT-IR gugus karbonil (ester) terbaca pada bilangan gelombang 1735,93 $\mathrm{cm}^{-1}$, Cincin aromatis yang ditunjukkan oleh serapan pada bilangan gelombang 1597,06 $\mathrm{cm}^{-1}$ dan gugus metoksi yang ditunjukkan oleh serapan pada $1242,16 \mathrm{~cm}^{-1}$ sedangkan gugus hidroksil terlihat pada serapan bilangan gelombang $3448,72 \mathrm{~cm}^{-1}$. Dari data IR dan mass peaks MS tersebut kemungkinan adalah 1-(3-metoksi-4hidroksi-fenil)-2-propanil asetat. 
Sifat Fisik Hasil Pemisahan dengan Kromatografi Kolom

Identifikasi fisik pemisahani sampel hasil sintesis dengan kromatografi kolom dalam bentuk wujud, warna, dan bau. Hasil identifikasi sifat fisik dilihat pada Tabel 2.

Tabel 2.Sifat Fisik hasil pemisahan dengan kromatografi kolom

\begin{tabular}{ccc}
\hline No & Sifat fisik & Keterangan \\
\hline 1 & Wujud & Cair \\
\hline 2 & Warna & Kuning pekat \\
\hline 3 & Bau & $\begin{array}{c}\text { Minyak cengkeh } \\
\text { (sedikit menyengat) }\end{array}$ \\
\hline
\end{tabular}

\section{KESIMPULAN}

Berdasarkan hasil penelitian yang telah dilakukan dapat disimpulkan bahwa berdasarkan analisis dengan FT-IR dan GC-MS teridentifikasi kemungkinan adanya senyawa 1-(3,4-dimetoksifenil)-2propanil asetat dengan kadar persentase sebesar $45,87 \%$ sedangkan berat molekulnya yaitu 238 .

\section{DAFTAR PUSTAKA}

Andriyani. 2008. Sintesis Metileugenol format dengan Cara Adisi Metil Eugenol dengan Asam Format. [Skripsi]. Jogjakarta: FMIPA, Universitas Islam Indonesia.

Ariens E.J. 1987. Rasemat-an Impediment In The Use Of Drugs and Agrochemicals. New York : Jhon Willey and Sons.

Caswell, M.A.G. Garibay, J.R. Scheffer, J.Trotter. 1993. Optical Activity Can $\mathrm{Be}$ Created from "Nothing". J.Chem.Educ. 70(10):785-787.

Fatoni A. 2005. Sintesis 3-(3,4dimetoksifenil)-1-propanol melalui Hidroborasi Metileugenol Menggunakan H3B:dietileter. [Skripsi]. Semarang: FMIPA UNDIP.
Fendy, 2007. Molekul Kiral Dari "Thalidomide" Sampai "LDOPA". (http://www.kimianet.lipi.go.i d/utama.cgi), diakses pada tanggal 8 Mei 2015.

Fessenden dan Fessenden, 1982. Kimia Organik Edisi Ketiga jilid 1. Jakarta: Erlangga.

Muchalal, dan Trisultyaningsi R, 2002. Isolasi dan Identifikasi Produk Utama serta Produk Samping Reaksi Adisi Kariofilen Oksida dengan Asam Formiat. Indonesian Journal of Chemistry. 2(3):155-160.

Ngadiwiyana, Ismiyarto dan A.R.K. Ariany, 2007. Oksidasi 3-(3,4dimetoksifenil) propanol dengan menggunakan Oksidator Piridinium Klorokromat (PCC). JSKA. 10(3).

Putri. R.L, Nur. H dan Nur. L. Rahma, 2014. Pemurnian Eugenol Dari Minyak Daun Cengkeh Dengan Reaktan Basa Kuat Koh Dan $\mathrm{Ba}(\mathrm{Oh})_{2} \quad$ (Kajian Konsentrasi Reaktan. Jurnal Industria 3(1):1-12.

Rahim, E. A, 2015. Sintesis Senyawa (S)(3,4-Dimetoksifenil)-2-Propanol Dari Metil Eugenol Tanpa Pengaruh Senyawa Optis Aktif. [Laporan Penelitian]. Palu: Fakultas MIPA Universitas Tadulako.

Sohilait, H.J, Sastrohamidjojo, H, Matsjeh, S and Grossert, J.S, 2005. Sintesis Analog L-alfa-metil-Dopa dari Eugenol. Indo, J. Chem. 5(3):198202.

White, C.A, 1991. An Introduction To Large Scale Enantioseparation. England: Elis Horwood Series.

Widowati R. 2011. Sintesis 1-(3,4Dimetoksi Fenil)-2-Propanon Dari Metil Eugenol. [Tesis]. Semarang: FMIPA Universitas Negeri Semarang. 